\title{
Statistical Note on the Components of Ocular Refraction in Twins*
}

\author{
ARNOLD SORSBY and G. R. FRASER
}

From the Wernher Research Unit on Ophthalmological Genetics (M.R.C.) and the Godfrey Robinson Unit (R.N.I.B.) at the Royal College of Surgeons of England and the Royal Eye Hospital, London

In their study on refraction and its components in twins, Sorsby, Sheridan, and Leary (1962) showed that the differences in measurements of the individual components were slight in 78 pairs of uniovular twins, in contrast to the distinctly larger differences observed in 40 pairs of binovular twins and 48 control pairs.

The differences in uniovular twins were slight even when the 23 pairs with non-modal refractions (spherical refractions of $\pm 2.25 \mathrm{D}$. or more; or astigmatism of $\pm I .25 \mathrm{D}$. or more) were considered; and this pattern likewise held when only the Io pairs with refraction of $\pm 4^{\circ} \circ \mathrm{D}$. or the 18 pairs with myopia (of varying degree above $0.50 \mathrm{D}$.) were studied; the binovular twins and the control pairs showed consistently larger differences in their measurements. There was also close agreement in the ocular refraction of uniovular twins, 55 pairs showing differences in refraction of less than $0.5 \mathrm{D}$. In the 18 pairs where the refraction differed by $0.5 \mathrm{I} \mathrm{D}$. to $\mathrm{I} \cdot 5 \mathrm{D}$. and the 5 pairs with a difference of more than I.5 D.- designated here discordant refractions-the individual components still showed close values, the difference in refraction usually being determined by slight non-concordance in the axial length. In contrast, no such consistent pattern could be seen in the binovular twins and the control pairs. The general analysis thus established that there was concordance for refraction and its components in the different types of refraction in uniovular twins, a striking contrast to the lack of any such concordance in the control material.

The present note attempts to evaluate statistically the findings recorded in that study. Statistical treatment has limitations where small numbers are available: this is a relevant consideration here for, as the twin material was largely a random collection representative of the general population, the higher (and unusual) refractive errors were poorly represented. There were none or but few cases in some of the refraction groups, but the material is

\footnotetext{
* Received February 6, 1964
}

none the less sufficiently extensive to warrant further analysis.

As in the previous study, only the right eye of a subject was assessed, except in such cases where values were available only for the left eye. The classification and criteria used were continued for this statistical note.

\section{Coefficients of Correlation}

Table I sets out the correlation coefficients in the uniovular twins, in binovular twins, and in random control pairs of similar age and sex. It will be seen that in the 3 series the coefficients approach the values expected on the hypothesis of quantitative inheritance due to a number of genes with additive effects and without dominance: unity for the uniovular twins, 0.5 for the binovular twins, and zero for the controls. This pattern also holds good when the larger groups of refractive errors in each series are considered separately. In the uniovular series several values depart markedly from expected unity only when smaller numbers, such as 3 and 5 individuals with moderate and high myopia, are considered; but when the smaller groups are taken together, i.e. all cases over $+2 \cdot 25 \mathrm{D}$., or all cases of $-0.5 \mathrm{D}$. and over, the approximation to unity is good. Much the same applies to the binovular twins and the control pairs with their expected coefficient of 0.5 and 0 . This is seen from the summary Table IA based on Table I.

Three special classes of cases shown in Table II call for additional consideration.

(I) The 23 pairs of uniovular twins with nonmodal refraction, i.e. spherical refraction of $\pm 2 \cdot 25$ $D$. or more, or cylindrical errors of $\pm I \cdot 25 \mathrm{D}$. or more: the coefficients of correlation for the different components in these exceptional refractions were high, ranging between 0.853 for the lens and 0.935 for axial length. Coefficients ranging between 0.237 and 0.675 were observed in the binovular twins and between 0.278 and -0.315 for the control pairs.

(2) There were I2 pairs of uniovular twins one or 
TABLE I

COEFFICIENTS OF CORRELATION IN THE DIFFERENT REFRACTION GROUPS

\begin{tabular}{|c|c|c|c|c|c|}
\hline \multirow[b]{2}{*}{$\begin{array}{c}\text { Refraction Group } \\
\text { (D.) }\end{array}$} & \multirow{2}{*}{$\begin{array}{l}\text { No. Within } \\
\text { Refraction } \\
\text { Group }\end{array}$} & \multicolumn{4}{|c|}{ Coefficient of Correlation } \\
\hline & & $\begin{array}{l}\text { Power of } \\
\text { Cornea }\end{array}$ & $\begin{array}{l}\text { Depth of } \\
\text { Anterior } \\
\text { Chamber }\end{array}$ & $\begin{array}{l}\text { Power of } \\
\text { Lens }\end{array}$ & $\begin{array}{c}\text { Axial } \\
\text { Length }\end{array}$ \\
\hline $\begin{array}{l}\text { All } \\
+4.01 \text { and over } \\
+2.26 \text { to }+4.00 \\
+0.51 \text { to }+2.25 \\
0.00 \text { to }+0.50 \\
-0.01 \text { to }-0.50 \\
-0.51 \text { to }-2.25 \\
-2.26 \text { to }-4.00 \\
-4.01 \text { and over } \\
\end{array}$ & $\begin{array}{r}156 \\
13 \\
6 \\
61 \\
40 \\
12 \\
16 \\
3^{1} \\
5^{1} \\
\end{array}$ & $\begin{array}{l}0.934 \\
0.858 \\
0.931 \\
0.921 \\
0.899 \\
0.879 \\
0.922\end{array}$ & $\begin{array}{l}0.827 \\
0.917 \\
0.890 \\
0.749 \\
0.926 \\
0.856 \\
0.836\end{array}$ & $\begin{array}{l}0.831 \\
0.911 \\
0.976 \\
0.761 \\
0.879 \\
0.944 \\
0.930\end{array}$ & $\begin{array}{l}0.919 \\
0.755 \\
0.619 \\
0.902 \\
0.875 \\
0.839 \\
0.570^{\star \star}\end{array}$ \\
\hline $\begin{array}{l}\text { All } \\
+4.01 \text { and over } \\
+2.26 \text { to }+4.00 \\
+0.51 \text { to }+2.25 \\
0.00 \text { to }+0.50 \\
-0.01 \text { to }-0.50 \\
-0.51 \text { to }-2.25 \\
-2.26 \text { to }-4.00 \\
-4.01 \text { and over }\end{array}$ & $\left.\begin{array}{r}80 \\
4 \\
11 \\
37 \\
17 \\
4 \\
4 \\
3 \\
0\end{array}\right\}$ & $\begin{array}{l}0.591 \\
0.761 \\
0.494 \\
0.659 \\
0.755\end{array}$ & $\begin{array}{r}0.452 \\
0.306 \\
0.474 \\
0.471 \\
-0.290\end{array}$ & $\begin{array}{l}0.507 \\
0.385 \\
0.568 \\
0.398 \\
0.647\end{array}$ & $\begin{array}{l}0.482 \\
0.615 \\
0.317 \\
0.344 \\
0.203\end{array}$ \\
\hline $\begin{array}{l}\text { All } \\
+4.01 \text { and over } \\
+2.26 \text { to }+4.00 \\
+0.51 \text { to }+2.25 \\
0.00 \text { to }+0.50 \\
-0.01 \text { to }-0.50 \\
-0.51 \text { to }-2.25 \\
-2.26 \text { to }-4.00 \\
-4.01 \text { and over }\end{array}$ & $\begin{array}{l}96 \\
8 \\
11 \\
32 \\
30 \\
4^{1} \\
6 \\
5^{1} \\
0\end{array}$ & $\begin{array}{r}0.075 \\
-0.051 \\
-0.311 \\
0.050 \\
0.356 \\
0.147\end{array}$ & $\begin{array}{l}0.358 \star \star \\
0.550 \\
0.212 \\
0.431^{\star} \\
0.401^{\star} \\
-0.396\end{array}$ & $\begin{array}{l}0.303^{\star \star} \\
-0.401 \\
-0.034 \\
-0.182 \\
0.575^{\star \star} \\
0.190\end{array}$ & $\begin{array}{l}0.037 \\
-0.420 \\
-0.501 \\
-0.148 \\
0.473^{\star \star} \\
0.451\end{array}$ \\
\hline
\end{tabular}

TABLE IA

COEFFICIENTS OF CORRELATION FOR THE COMPONENTS OF THE MAJOR REFRACTION GROUPS IN THE THREE SERIES OF PAIRS

\begin{tabular}{|c|c|c|c|c|c|}
\hline \multirow[b]{2}{*}{ Refraction Group } & \multirow{2}{*}{$\begin{array}{l}\text { No. Within } \\
\text { Refraction } \\
\text { Group }\end{array}$} & \multicolumn{4}{|c|}{ Coefficient of Correlation } \\
\hline & & $\begin{array}{l}\text { Power of } \\
\text { Cornea }\end{array}$ & $\begin{array}{l}\text { Depth of } \\
\text { Anterior } \\
\text { Chamber }\end{array}$ & $\begin{array}{l}\text { Power of } \\
\text { Lens }\end{array}$ & $\begin{array}{c}\text { Axial } \\
\text { Length }\end{array}$ \\
\hline $\begin{array}{l}\text { All Refractions } \\
\text { Uniovular pairs } \\
\text { Binovular pairs } \\
\text { Control pairs }\end{array}$ & $\begin{array}{r}\text { I } 56 \\
80 \\
96\end{array}$ & $\begin{array}{l}0.934 \\
0.591 \\
0.075\end{array}$ & $\begin{array}{l}0.827 \\
0.452 \\
0.358 \star \star\end{array}$ & $\begin{array}{l}0.831 \\
0.507 \\
0.303^{\star \star}\end{array}$ & $\begin{array}{l}0.919 \\
0.482 \\
0.037\end{array}$ \\
\hline $\begin{array}{l}\text { Emmetropes (0.0 to } 0.50 \mathrm{D} .) \\
\text { Uniovular pairs } \\
\text { Binovular pairs } \\
\text { Control pairs }\end{array}$ & $\begin{array}{l}40 \\
17 \\
30\end{array}$ & $\begin{array}{l}0.899 \\
0.659 \\
0.356\end{array}$ & $\begin{array}{l}0.926 \\
0.471 \\
0.401 *\end{array}$ & $\begin{array}{l}0.879 \\
0.398 \\
0.575^{\star \star}\end{array}$ & $\begin{array}{l}0.875 \\
0.344 \\
0.473^{\star \star}\end{array}$ \\
\hline $\begin{array}{l}\text { Low Hypermetropes } \\
\text { (0.5I to } 2.25 \text { D.) } \\
\text { Uniovular pairs } \\
\text { Binovular pairs } \\
\text { Control pairs }\end{array}$ & $\begin{array}{l}61 \\
37 \\
32\end{array}$ & $\begin{array}{l}0.921 \\
0.494 \\
0.050\end{array}$ & $\begin{array}{l}0.749 \\
0.474 \\
0.43 I^{\star}\end{array}$ & $\begin{array}{r}0.761 \\
0.568 \\
-0.182\end{array}$ & $\begin{array}{r}0.902 \\
0.317 \\
-0.148\end{array}$ \\
\hline $\begin{array}{l}\text { High Hypermetropes } \\
\text { (2.26 D. and over) } \\
\text { Uniovular pairs } \\
\text { Binovular pairs } \\
\text { Control pairs }\end{array}$ & $\begin{array}{l}19 \\
15 \\
19\end{array}$ & $\begin{array}{r}0.882 \\
0.759 \\
-0.126\end{array}$ & $\begin{array}{l}0.892 \\
0.317 \\
0.346\end{array}$ & $\begin{array}{r}0.925 \\
0.351 \\
-0.263\end{array}$ & $\begin{array}{l}0.735^{\star} \\
0.607 \\
-0.511^{\star}\end{array}$ \\
\hline $\begin{array}{l}\text { All Myopes over - }-0.5 \mathrm{I} \mathrm{D} . \\
\text { Uniovular pairs } \\
\text { Binovular pairs } \\
\text { Control pairs }\end{array}$ & $\begin{array}{r}24 \\
7 \\
11\end{array}$ & $\begin{array}{r}0.926 \\
0.755 \\
-0.235\end{array}$ & $\begin{array}{r}0.947 \\
-0.290 \\
-0.265\end{array}$ & $\begin{array}{l}0.843 \\
0.647 \\
0.305\end{array}$ & $\begin{array}{l}0.735^{\star \star} \\
0.203 \\
-0.127\end{array}$ \\
\hline
\end{tabular}

1 Coefficients not calculated for groups of less than six.

Note: Tests of significance were performed using Fisher's $z$ transformation. In the case of binovular twins difference from 0.5 is tested $\square$ and in the case of controls the difference from zero. In the case of uniovular twins each sub-group is tested to determine whether the correlation $\bar{O}$ coefficient is lower than in the group as a whole.

One asterisk denotes significance at $5 \%$ level of probability, two at $1 \%$ level. 
TABLE II

COEFFICIENTS OF CORRELATION IN SOME SPECIFIC GROUPS

\begin{tabular}{|c|c|c|c|c|c|c|c|}
\hline \multirow[b]{2}{*}{ Groups } & & \multirow{2}{*}{$\begin{array}{l}\text { No. of Pairs } \\
\text { (one or both } \\
\text { of which fall } \\
\text { within } \\
\text { group) }\end{array}$} & \multirow{2}{*}{$\begin{array}{l}\text { No. of } \\
\text { Subjects }\end{array}$} & \multicolumn{4}{|c|}{ Coefficient of Correlation } \\
\hline & & & & Cornea & $\begin{array}{l}\text { Depth of } \\
\text { Anterior } \\
\text { Chamber }\end{array}$ & Lens & $\begin{array}{c}\text { Axial } \\
\text { Length }\end{array}$ \\
\hline Non-modal refractions ${ }^{1}$ & $\left\{\begin{array}{l}\mathbf{U} \\
\mathbf{C}\end{array}\right.$ & $\begin{array}{l}23 \\
19 \\
23\end{array}$ & $\begin{array}{l}41 \\
24 \\
28\end{array}$ & $\begin{array}{r}0.886 \\
0.675 \\
-0.049\end{array}$ & $\begin{array}{l}0.878 \\
0.237 \\
0.278\end{array}$ & $\begin{array}{r}0.853 \\
0.473 \\
-0.186\end{array}$ & $\begin{array}{r}0.935 \\
0.239 \\
-0.315\end{array}$ \\
\hline $\begin{array}{l}\text { Eyes with axial length } \\
\text { outside the emmetropic } \\
\text { ranget }\end{array}$ & $\left\{\begin{array}{l}\mathbf{U} \\
\mathbf{B}\end{array}\right.$ & $\begin{array}{r}12 \\
8 \\
14\end{array}$ & $\begin{array}{r}20 \\
9 \\
15\end{array}$ & $\begin{array}{l}0.886 \\
0.787 \\
0.616\end{array}$ & $\begin{array}{l}0.928 \\
0.054 \\
0.442\end{array}$ & $\begin{array}{r}0.862 \\
0.570 \\
-0.236\end{array}$ & $\begin{array}{r}0.970 \\
0.167 \\
-0.146\end{array}$ \\
\hline Discordant refractions $\ddagger$ & $\left\{\begin{array}{l}\mathbf{U} \\
\mathbf{B} \\
\mathbf{C}\end{array}\right.$ & $\begin{array}{l}23 \\
28 \\
34\end{array}$ & $\begin{array}{l}46 \\
56 \\
68\end{array}$ & $\begin{array}{r}0.880 \\
0.533 \\
-0.042\end{array}$ & $\begin{array}{l}0.890 \\
0.463 \\
0.169\end{array}$ & $\begin{array}{l}0.898 \\
0.404 \\
0.091\end{array}$ & $\begin{array}{l}0.793^{\star \star} \\
0.405 \\
-0.225\end{array}$ \\
\hline
\end{tabular}

1 Spherical errors of $\pm 2.25 \mathrm{D}$. or more, or cylindrical errors of more than $\pm 1 \cdot 25 \mathrm{D}$.

+ Taken here as 22.5 to $25.9 \mathrm{~mm}$.

$\ddagger$ Refractions differing by $>0.5 \mathrm{D}$. in the pair of twins (or controls).

Note: $\mathrm{U}=$ Uniovular; $\mathrm{B}=$ Binovular; $\mathrm{C}=$ Control.

$\star \star$ Significant at $\mathbf{I} \%$ level.

both of whom had an axial length falling outside the range seen in emmetropic eyes, as defined in two earlier studies by Sorsby and his associates (Sorsby, Benjamin, Davey, Sheridan, and Tanner, 1957; Sorsby, Benjamin, and Sheridan, 1961) and taken here as 22.5 to $25.9 \mathrm{~mm}$. The coefficients for the components of refraction in these 12 pairs, all eyes with high refractive errors, were close to unity (ranging from 0.862 to 0.970 ). Nothing approaching such values was seen for the corresponding 8 pairs of binovular twins and I4 control pairs.

(3) There were 23 pairs of uniovular twins with discordant refractions, i.e. the partners showed a difference in refraction of $0.5 \mathrm{I} \mathrm{D}$. or more. Here, too, the components of refraction showed a high correlation coefficient, the lowest being 0.793 for axial length. The coefficients for binovular twins were close to the expected 0.5 and those of the control pairs to the expected zero.

The statistical treatment recorded here bears out the conclusions reached in the published monograph. It emphasizes the marked concordance for uniovular twins as opposed to binovular twins, and confirms that of all the components, the axial length shows the largest, though still very limited, tendency to depart from expectation on the hypothesis of quantitative inheritance. Several correlation coefficients (marked with an asterisk) among the control pairs depart significantly from zero in a positive direction at the $5 \%$ level of probability. This is possibly due to the fact that they are matched for age and sex. Since half of the control individuals are children of 4-13 years of age in whom the components of refraction are not finalized, this could have the effect of making the pairs more alike than subjects chosen at random and unmatched for these variables.

\section{Summary}

A statistical assessment is given of the data recorded by Sorsby and his associates on the components of ocular refraction in 78 pairs of uniovular twins, 40 pairs of binovular twins, and 48 control pairs. In the three series the coefficients of correlation approach the values expected on the hypothesis of quantitative inheritance due to a number of genes with additive effects and without dominance: viz., unity for uniovular twins, 0.5 for binovular twins, and zero for controls. These findings apply equally to the different types of ametropia and to emmetropia.

\section{REFERENCES}

Sorsby A., Benjamin, B., Davey, J. B., Sheridan, M., and Tanner, J. M. (1957). Emmetropia and its aberrations. Spec. Rep. Ser. med. Res. Coun. (Lond.), No. 293.

- - - and Sheridan, M. (I96I). Refraction and its components during the growth of the eye. Spec. Rep. Ser. med. Res. Coun. (Lond.), No. 301 .

-, Sheridan, M., and Leary, G. A. (1962). Refraction and its components in twins. Spec. Rep. Ser. med. Res. Coun. (Lond.), No. 303. 